\title{
ADMINISTRASI PEMBELAJARAN GURU MI BERBASIS MEDIA PADA YAYASAN ISLAHUL UMMAH NW DESA PERESAK BATUKLIANG LOMBOK TENGAH
}

\author{
Syukri \\ Institut Agama Islam Negeri Mataram \\ E-mail: syukri yun@yahoo.com
}

\begin{abstract}
Abstrak: Dalam melakukan kegiatan proses pendidikan dan pembelajaran, seorang guru mutlak mendasari kegiatannya berdasarkan administrasi pembelajaran, termasuk pembelajaran berbasis media. Media yang dimaksud dalam tulisan ini adalah media yang menjelaskan materi, atau media yang dapat membantu guru untuk memudhakan siswa memahami materi ajar yang sedang disampaikan guru. Adapun beberapa langkah administrasi pembelajaran berbasis media, yaitu membuat perencanaan, terutama perencanan menyangkut media apa saja yang akan dibawa dalam proses pembelajaran selama satu semester, kemudian menyusun rencana pelaksanaan pembelajaran (RPP) dan terakhir guru melaksanakan proses pembelajaran yang semua materi dapat dijelaskan dengan bantuan materi dan tentu saja guru selalu membawa media pada saat memasuki ruangan kelas. Pengakuan para guru menunjukkan bahwa mengajar dengan disertai media yang dapat menjelaskan materi sangat memudahkan siswa dan siswi mudah mengerti materi yang sedang disampaikan dan lebih menggembirakan lagi bahwa ternyata siswa sangat cepat paham dan mengerti setelah menjelaskan disertai media dan yang lebih baik lagi bahwa siswa tidak saja cepat paham dan mudah mengerti, akan tetapi juga lama ingat karena para murid memahami materi disertai melihat sendiri secara langsung pokok permasalahan yang sedang dipelajari dengan bantuan media konkrit di depan mata mereka.
\end{abstract}

Kata kunci: Administrasi Pembelajaran, Pembelajaran Berbasis Media, Media Visual.

\section{PENDAHULUAN}

Administrasi pemberdayaan lembaga pendidikan sangat penting dilakukan bagi lembaga pendidikan kurang maju dan dan juga lembaga tersebut belum pernah dilakukan program pendampingan dalam memajukan lembag itu. Sama halnya menimpa yayasan Islahul Ummah Nahdatul Wathan yang mengelola Madrasah Ibtidaiyah berlokasi di Dasan Aman Peresak Batukliang Lombok Tengah yang masih menggunakan pengelolaan lembaga pendidikan bersifat tradisional, terutama dalam administrasi pembelajaran yang dilaksanakan oleh dewan guru. Kepala madrasah kurang memiliki kemampuan manajerial yng sempurna untuk menata administrasi pembelajaran di dalam kelas, teutaa berkaitan dengan administrasi pembelajaran berbasis media. Para guru belum diarahkan untuk membuat RPP yang mengutamakam adanya media dalam setiap membuat perencanaan pembelajaran di kelas. Untuk itu, kepala madrasah harus jeli dan 
Transformasi, Vol. 12, No. 1, Januari 2016: 31-45

cermat menemukan dalam RPP para guru untuk mendorong mereka lebih kreatif dan inovatif dalam penyusunan RPP yang di dalamnya memuat ada media konkrit dalam proses pembelajaran.

Beberapa alasan yang menjadi dasar pemilihan subyek adalah; Pertama, administrasi pembelajaran guru MI berbasis media pada yayasan NW Islahul Ummah relatif kurang menyadari perlunya pembelajaran berbasis media pada semua mata pelajaran. Kedua, administrasi pembelajaran guru MI kurang terlatih dan terampil menyapkan media dalam setiap proses pembelajaran pada mata pelajaran yang akan mereka ajarkan. Ketiga, pola pengelolaan administrasi pembelajaran bersifat tradisional karena tidak dibekali dengan pengetahuan dan ketrampilan mempersiapkan media sebelum proses pembelajaran berlangsung, seperti, perencanaan media, cara penggunaan media, tahap-tahap penggunaan media, dan cara menggunakan media sesuai kontek materi yang diajarkan erta cara mengevaluasi penggunaan media dalam proses pembelajaran.

Adapun kondisi MI Islahul Ummah Nahdatul Wathan (NW) Dasan Aman desa Peresak kecamatan Batukliang kabupaten Lombok Tengah saat ini bahwa sekolah ini dalam melakukan pengajaran tanpa ada media yang dapat memperkuat pemahaman materi yang mereka ajarkan kepda sisiwanya. Guru Madrasah Ibtidaiyah NW Dasan Aman desa Peresak kecamatan Batukliang kabupaten Lombok Tengah masuk kelas tanpa persiapan media yang membantu pemahaman dan penguatan ingatan materi, sehingga mengabaikan tahap kognitif mereka yang sangat memerlukan penguatan dan penjelasan tambahan.

Dalam melaksanakan kegiatan ini, ada tiga strategi yang digunakan dalam melaksnakan pengabdian pada madrasah yaitu; pertama, melaksanakan workshop (pelatihan) kepada para dewan guru. Dalam melaksanakan pelatihan ini, para guru diberikan teori menyangkut media terkait materi yang kan diajarkan dalam kelas. Salah satunya adalah media yang dapat menjelaskan materi tersebut, bukan media sekedar alat seperti papan atau kapur. Media yang diaksud dalam pembelajaran adalah media yang dapat membantu menjelaskan materi yang sedang dibahas. Misalnya, guru menjelaskan masalah alat-alat ukur dan alat berat dalam pelajaran IPA, maka guru wajib membawa penggaris, jangkar, dan juga alat timbang. Kedua, menferivikasi media yang digunakan guru. Sesuai kesepakatan antara pemateri dengan dewan guru bahwa sehari setelah 
memperoleh materi, keesokan harinya para guru mulai menyiapkan media yang disesuaikan materi yang akan mereka ajarkan minggu depan di kelas. Dari 10 orang guru, mereka semua membawa media sesuai materi yang mereka ajarkan. Ketiga, melakukan pendampingan kepada semua guru. Mhasiswa KKP semester VII diminta memberikn pendampngan selama berada di lokasi KKP untuk memnatau dan membantu para guru menyiapkan media sesuai kebutuhan para guru. Demikian juga pemateri selaku kepala Madrash Aliyah Ust. Alwi Farhkanuddin, M.Ag menjadi pendamping guru MI dalam melaksanakan proses pembelajaran berbasis media. Keempat, refleksi. Sebagai akhir dari kegiatan pengabdian, para guru diminta untuk memberikan pendapat sehubungan dengan materi yang mereka berikan dan juga bagaimana melakukan persiapan media yang akan mereka gunakan sesuai materi yang mereka ajarkan.

Beberapa pihak yang terkait dalam madrasah yang akan terlibat dalam kegiatan pengabdian kepada madrasah, khususnya pembinaan guru MI ini adalah: Pertama, kepala Madrasah Ibtidaiyah NW Dasan Aman desa Peresak kecamatan Batukliang kabupaten Lombok Tengah. Kepala madrasah Ibtidaiyah Islahul Ummah adalah subyek utama yang mendorong para guru MI senantiasa menggunakan media konkrit selama dalam proses pembelajaran. Kedua, guru.subyek perantara yang menjalankan pembelajaran berbasis media mulai dari perencanaan, penyusunan RPP sampai penyediaan media pendukung materi pembelajaran. Ketiga, mahasiswa KKP yang ada di lokasi desa Peresak kecamatan Batukliang kabupaten Lombok Tengah untuk membantu memberi pendampingan kepada para guru madrasah Ibtidaiyah Islahul Ummah selama mereka berpartisipasi dalam kegiatan kuliah lapangannya. Keempat, siswa adalah obyek utama dalam kegiatan proses pembelajaran. Kelima, pengabdi sebagai narasumber, observer dan evaluator yaitu mengamati dan menilai tata kelola yang tepat atau tidaknya manajemen administrasi pembelajaran berbasis media yang telah dilakukan para dewan guru.

Secara umum, lembaga pendidikan Madrasah Ibtidaiyah yayasan Islahul Ummah NW Dasan Aman desa Peresak kecamatan Batukliang kabupaten Lombok Tengah memiliki gedung dan fasilitas pendidikan dan pembelajaran, seperti meja dan kuris serta papan. Akan tetapi dari sisi media pembelajaran sangat kurang dan nyaris nihil. Bagi Madrasah Ibtidaiyah memiliki kepala sekolah, wakil kepala 
Transformasi, Vol. 12, No. 1, Januari 2016: 31-45

sekolah dan dewan guru sebanyak 12 orang. Mereka terdiri dari guru kelas, guru agama dan guru olah raga. Guru kelas sebanyak 10 orang, selebihnya masingmasing

Di amping itu Madrasah Ibtidaiyah yayasan Islahul Ummah NW DasanAman desa Peresak kecamatan Batukliang kabupaten Lombok Tengah memiliki siswa dan siswi realtif kecil yaitu sebanyak 66 orang dengan jumlah guru sebanyak 14 orang guru. Adapun mayoritas guru yang mengajar sudah mendapat pendidikan sarjana strata satu, namun masih ada guru yang masih diajar oleh orang yang masih memperoleh pendidikan pada tingkat menengah atas. Tentu saja, guru Madrasah Ibtidaiyah yayasan Islahul Ummah NW Dasan Aman desa Peresak kecamatan Batukliang kabupaten Lombok Tengah tidak semua menamatkan diri pada jenjang pergurua tinggi sebagaimana diamanatkan undang-undang tentang sistem pendidikan nasional, di mana guru harus diajarkan oleh guru yang sudah mengantongi ijazah S.1. Dengan demikian mash sangat banyak guru yang belum memperoleh tunjangan sertifikat guru, karena kendala faktor ijazah.

Dengan demikian keberadaan dan dan kelanjutan proses pembelajaran di kalangan Madrasah Ibtidaiyah yayasan Islahul Ummah NW DasanAman desa Peresak kecamatan Batukliang kabupaten Lombok Tengah tetap berjalan sesuai rencana dan apa adanya. Para guru dan segenap keluarga besar yayasan Islahul Ummah NW Dasan Aman desa Peresak kecamatan Batukliang kabupaten Lombok Tengah terus bahu membahu membangun dan melaksanakan proses pendidikan dan embelajaran baik tingkat pra sekolah sampai tingkat menengah atas. Khusus pada Madrasah Ibtidiyah, para guru senantiasa rajin menjalankan tugas dan fungsinya sebagai guru, baik sebagai guru kelas maupun guru bidang studi, seperti guru Olahraga dan Penjaskes.

Adapun instrumen pengabdian yang digunakan dalam melaksanakan kegiatan pengabdian pada madrasah binaan adalah; Pertama, melakukan survey awal pada madrsah. Survey awal dilakukan sebagai upaya mencari informasi dan mendapatkan data riil tentang keberadaan sekolah dan keadaan guru terutama dalam proses pembelajaran, mulai dari perencanan penggunaan media, penyediaan media, operasional penggunaan media dan evaluasi penggunaan media. Kedua, melakukan wawancara dengan kepala sekolah, dan para dewan guru. Kegiatan ini dilakukan untuk mendapatkan pemahaman dan gambaran 
umum tentang apa yang sedang dialami, dirasakan, dan dihadapi baik kepala sekolah maupun oleh dewan guru terkait masalah penggunaan dalam kelas. Ketiga, melakukan observasi. Kegiatan observasi dilakukan pada suasana perkantoran maupun pada suasana belajar. Kegiatan observasi pada perkantoran untuk mengetahui secara pasti kegiatan kepala sekolah beserta jajaran pejabat atau pengelola administrasi. Kelihatannya suasana administrasi sangat sederhana dan tidak menunjukkan suasana kesibukan yang sangat signifikan, sebab ruangan kepala sekolah dengan staf administrasi menyatu dan hanya beberapa orang yang mengerjakannya. Maklum siswa yang dikelola juga sedikit, yaitu sebanyak 66 orang siswa dan siswi.

\section{PEMBAHASAN}

Sesuai dengan hasil workshop bersifat teoritis di mana seorang guru wajib membuat rencana pelaksanaan pembelajaran (RPP), yang didalamnya terdapat beberapa unsur dalam melaksanakannya. Pertama, tahap perencanaan. Dalam tahap ini para guru berhasil membuat perencanaan dengan membuat catatan dan menentukan sendiri media yang akan direncanakan itu. Misalnya pada hari pertama usai pelatihan para ibu dan bapak guru semua membuat perencanaan menyiapkan media-media yang akan ajarakan sesuai materi yang akan dibahas. Dan pada hari kedua pada minggu kedua semua ibu dan bapak guru membawa media yang mereka siapkan dan rencanakan. Satu persatu para ibu dan guru beberkan media yang mereka bawa dan menjelaskan bagaimana ara mereka ajarkan kepada siswa dan siswinya.

Tahap, pemilihan media. Tahap ini sebagai wujud nyata ibu dan guru mampu memilih sendiri media yang dijadikan bahan ajar dalam menjelaskan materi yang akan mereka sampikan di hadapan siswa. Sebagai wujud keberhasilan mereka dalam memilih media yang meeka tetapkan adalah membawa media itu pada acara pelatihan hari kedua dan minggu kedua dalam ruangan pelatihan. Mereka semua guru yang berpartisipasi dalam kegiatan pelatihan itu membawa media yang mereka pilihkan sendiri.

Tahap penentuan media. Mengingat banyaknya media yang akan disiapkan dalam proses pembelajaran, maka guru sangat selektif memilih media yang ada kemudian menentukan berbagai pilihan yang ada. Untuk menentukan media yang 
akan dipilih, tentu saja media yang sudah dibawa dalam kelas adalah media yang bisa menjelaskan materi, bukan sekedar media. Para ibu dan bapak guru sudah menyiapakn media sesuai dengan tuntutan materi yang akan mereka ajarkan, misalnya ibu guru akan mengajarkan tata cara berwudhu, maka guru membawa gambar berwudhu kepada para siswa.

Tahap, pelaksanaan pembelajaran. Berikut pengakuan para bapak dan ibu guru Madrasah Ibtidaiyah Islahul Ummah Dasan Amman desa Peresak kecamatan Batukliang kabupaten Lombok Tengah yang telah melaksanakan proses pembelajaran berbasis media sesuai materi yang mereka ajarkan dalam kelas. Hasil pengakuan dan pernyataan ibu dan guru yang akan dipaparkan adlah berdasarkan catatan dan komentar mereka dalam lembaran yang sengaja diberikan kepada setiap guru. Mereka secara bebas menyampaikan pendapat tentang bagaimana hasil pengamatan ibu dan bapak guru Madrasah Ibtidaiyah Islahul Ummah Dasan Amman desa Peresak kecamatan Batukliang kabupaten Lombok Tengah terhadap siswanya setelah mereka menjelaskan materidengan dukungan media yang menjelaskan materi yang sudah mereka sampaikan di dalam kelas.

Pertama, ibu Hafsah. Ibu guru ini mengaku bahwa setelah ia menyampaikanmateri dengan menggunakan media kepada para siswa, maka hasilnya sangat baik sebab anak-anak dapat mengerti materi yang sudah disampaikan dengan dukungan media.

Kedua, ibu Ernita Yuliana. Ibu guru yang satu ini biasa mengajar pada kelaa III. Ia mengaku bahwa setelah disampaikan materi dengan dukungan media yang bisa menjelaskan materi, maka murid-muridnya mudah mengerti dan lama ingat. Ia sanagat senang dengan metode pembelajaran berbasis media.

Ketiga, ibu maryam. Ibu guru yang satu ini memberikan komentar terkait proses administrasi pembelajaran berbasis media pasca pelatihan yang sudah diikutinya selama dua hari mengtakan bahwa setelah menggunakan media pada saat sedang mengajar, maka siswa dan siswi mengalami ada kemajauan yang cukup baik karena dibandingkan dengan proses pembelajaran sebelumnya yakni sebelum tidak didukung dengan media pembelajaran, para siswa dan siswi sulit memhamai materi pelajaran yang sudah disampaikan, akan tetapi sesudah ada dukungan media terutama media yang ikut memperjelas materi yang akan 
disampaikan, maka para murid-murid umumnya mudah mengerti materi yang sudah disampaikan.

Keempat, ibu Khairiyah. Ibu guru yang rajin ini mengaku bahwa sesuai hasil pengamatan dan catatn dirinya setelah menyampaikan materi kepada para mridnya dengan dukungan media, maka hasil yang diperoleh menunjukkan bahwa siswa dan siswi dapat memahami dengan baik dan anak-anak juga mudah sekali memahamai materi pelajaran yang sudah disampaikan. Lebih lanjut ia mengatakan bahwa dengan menggunakan media sebagai penjelas materi, maka siswa sangat cepat paham dan tidak berasa bosan mengikuti pelajaran meskipun jamnya cukup lam.

Kelima, bapak guru Abdurrahim. Bapak guru kelas $\mathrm{V}$ ini dalam pengakuannya menyatakan bahwa berdasarkan pengamatan dirinya bahwa setelah ia menyampaikan materi pelajaran dengan dukungan media, maka anakanak mengalami ekmajuan, sebab setelah mengikuti pelajaran berbasis media, murid-muridnya mudah merespon pelajaran disampaikannya dan mereka juga mudah memahami materi pelajaran yang sudah disampaikan. Menurutnya, pola atau metode pembelajaran bebasis media dapat member motivasi belajar anak lebih tertarik dan menyenangkan serta dapat mengetahui dengan sesungguhnya ia siswa ada yang belum mengerti, maka guru juga dapat secepatnya memberikan bantuan menjelaskan kembali materi tersebut dengan dukungan media, yang akhirnya semua siswa tidak ada yang merasa susah memahami materi peljaan ayng sudah diajarkan.

Keenam, ibu Khusnul Khotimah. Ibu guru kelas VI ini mengaku bahwa murid-muridnya lebih cepat menangkap materi yang disampaikan dengan menggunakan media daripada menyampaikan materi secara lisan belaka. Ia menilai murid diajarkan sesuai permasalahan yang nyata bukan khayalan atau ilustrasi secara narasi saja. Lebih lanjut ia menyatakan bahwa metode berbasis media sangat tepat untuk diterapkan kepada anak-anak di bangku sekolah dasar/Ibtidaiyah karena anak-anak dapat menemukan sendiri apa yang menjadi materi pelajarannya. Bahkan dengan adanya temuan sendiri oleh anak-anak maka sangat sulit mereka melupakan pelajaran tersebut atau dalam perkataan lain bahwa dengan menemukan sendiri maka anak-anak akan selalu ingat mata pelajaran yang sudah mereka pelajari. 
Transformasi, Vol. 12, No. 1, Januari 2016: 31-45

Di samping itu, secara khusus pengabdi menanyakan kepada bapak Syamsul Mujahidddin terkait dengan hasil aplikasi administrasi pembelajaran berbasis media. Berdasarkan keterangan dan pengakuan Syamsul Mujahidin, S.Pd. I bahwa pelatihan administrasi pembelajaran berbasis media sangat menyentuh perhatian pihak sekolah. Para guru diberi pelatihan merasakan manfaat yang sngat besar karena mereka mengajar dengan media dan tahu siswa bisa mengerti atau tidak. Alat ukur melalui media dapat dijadikan sarana mengetahui daya serap siswa rendah atau tinggi. Hasilnya para siswa setelah menggunakan media penjelas materi, banyak siswa merasakan mudah memahami pelajaran. Yang lebih menggembirakan lagi kata Syamsul Mujahidin yaitu mampu merubah mindset guru yang semula enggan dan malas membuat RPP begitubegitu saja, akan tetapi setelah ada pelatihan yang memberikan nuansa baru tentang penyusunan RPP yang berbasis meduia, maka pihak sekolah menindak lanjut tentang bagaimana guru membuat RPP berbasis media. Para pengelola Madrasah Ibtidaiyah Islahul Ummah Dasan Amman desa Peresak kecamatan Batukliang kabupaten Lombok Tengah bersama dewan guru bersepakat untuk bertekad membuat administrasi lebih bagus lagi agar sebelum masuk kelas, para guru sudah memiliki perencanaan yang jelas, terutama mempersiapkan media apa yang akan disiapkan dalam berbagai mata pelajaran yag akan mereka ajarkan pada semester berikutnya. ${ }^{25}$ Tentu saja phak sekolah juga bisa membantu mempersiapkan bahan atau media yang sangat diperlukan selama atu semester sebagaimana kebutuhan guru yang akan diajarkan nanti.

Menilik berbagai komentar, pendapat dan ungkapan hati para ibu dan bapak guru Ibtidaiyah Islahul Ummah Dasan Amman desa Peresak kecamatan Batukliang kabupaten Lombok Tengah menunjukkan bahwa setelah ada pelatihan tentang administrasi pembelajaran berbasis media pada sekolah tersebut secara umum memiliki ada kemajuan disbanding sebelumnya. Ada dua hal yang dapat diambil hikmah dan manfaat dari proses pelatihan yang singkat itu yaitu; Pertama, adanya kesadaran guru Ibtidaiyah Islahul Ummah Dasan Amman desa Peresak kecamatan Batukliang kabupaten Lombok Tengah untuk merubah diri dan sekaligu sadar diri terhadap kekurangan yang ada dan mereka mau merubah diri. Bakan pihak sekolah ikut menyadari adanya kekurangan sekolah terhadap RPP yang

\footnotetext{
${ }^{25}$ Hasil wawancara dengan Syamsul Mujahidin, S.Pd.I, tanggal 10 Oktober 2016.
} 
dibiarkan kurang penting sehingga guru nyaris tidak membuat RPP setiap akan meulai pekerjaan sebagai guru setiap semester.

Kedua, adanya kemajuan yang signifikan yang diarasakan langsung oleh ibu dn bapk guru terhadap perubahan respons dan daya tangkap semua siswanya. Semua guru merasakan ada perubahan daya pemahaman siswa setelah adanya penyampaian materi yang dilengkapi dengan media yang ikut menjelaskan materi pelajaran. Ibu dan bapak guru Ibtidaiyah Islahul Ummah Dasan Amman desa Peresak kecamatan Batukliang kabupaten Lombok Tengah meraskan ada sesuatu yang sangat baik dari cara penyampaian mereka dalam mata pelajaran karena mereka merasakan sswa dan siswinya mudah memahami pelajaran, bahkan mereka bisa lama ingat dar materi pelajaran yang sudah dipelajarinya.

Tahap, evaluasi pembelajaan. Berdasarkan pengakuan para dewan guru Madrasah Ibtidaiyah NW Dasan Aman Peresak Batukliang Lombok Tengah tampak mereka mampu merencanakan dan memilih serta menetapkan media yang akan mereka siapakan dan bawa kan dalam ruangan kelas. Namun mereka melakukan perencanaaan, pemilihan dan penentuan media serta melakukan proses pembelajaran berbssis media di dalam kelas sebatas pada saat mereka disuruh dan ada pendampingan, akan tetapi ketika tidak ada pendampingan maka guru tidak membawa media lagi. Adapun alasan mereka tidak membawa media antara lain berbagai alasan sebgai berikut; Pertama, kendala kurangnya biaya dan anggaran. Ketika peneliti melakukan kunjungan mendadak di dalam kelas, ibu guru sedang mengajarkan asmaul husna pada kelas III. Ia hanya menulis di whiteboard yang kabur tentang empat nama asmaul husna yaitu al-kabir, aladhim, al-halim, dan al-ghafur. Keempat nama asmaul husna ditulis dalam huruf latin, bukan bahasa Arab. Penulis bertanya mengapa tidak dilengkapi degan media yang menjelaskan tentang bentuk kebesaran Allah dengan gambar nyata seperti; gambar ka'bah. Jawabannya bahwa guru tidak memiliki dana untuk membeli kertas sebab kertas yang diberikan peneliti sudah habis. Demikian juga ketika peneliti bertanya kepada ibu guru kelas VI tentang operasi Matematika masalah angka kelipatan kecil dan besar. Ia merasa kesulitan mejelaskan masalah dengan bantuan media. Di samping itu, adanya kendala biaya yang harus mereka keluarkan untuk membeli alat dan juga kalau sekear kertas juga kertasnya sudah habis, maka ibu guu tersebut tidak dapat menghadirkan media lagi. 
Transformasi, Vol. 12, No. 1, Januari 2016: 31-45

Kedua, faktor kemalasan. Faktor kemalasan adalah bentuk kurangnya kreatif guru untuk menyiapkan dan mengusahakan media yang sangat diperlukan dalam proses pembelajaran. Secara umumnya guru kurang diasah kreatifitasnya untuk menghadirkan media selama proses pembelajaran, apalagi jika tidak ada pendampingan yang terus menerus dari petugas atau guru lain yang merasa tanggung jawab yang tinggi dalam mengawasi jalannya pengggunaan media pada proses pembelajaran.

Sesuai dengan hasil yang diperoleh di lapangan baik secara prosedural formal maupun tidak formal menunjukkan bahwa tahap administrasi proses pembelajaran berbasisi media sungguh mendapat tantangan dan permasalahan tersendiri bagi guru dan pendampingan. Secara umum, para ibu dan bapak guru memiliki semangat yang tinggi dalam memajukan kualtas duia pendidikan, akan tetapi kenyataan di lapangan masih banyak kendala baik secara teknik maupun non teknis terkait proses pembelajaran dalam kelas berbasis media. Faktor non tekns terutama substansi peramasalahan adalah rendahnya tingkat penguasaan teori di kalangan ibu dan bapak guru, terutama teori pembelajaran dan juga teori media yang menjad pendukung utama sebuah keberhasilan siswa dalam proses pembelajaran. Dilihat dari sisi pengetahuan, ibu dan guru Madrasah Ibtidaiyah Islahul Ummah Dasan Amman desa Peresak kecamatan Batukliang kabupaten Lombok Tengah sangat kurang menguasai pengetahuan teoritis sehingga dalam berbagai pendapat pakar terkait media banyak tidak memenuhi harapan para pakar. Pada umumnya para pakar media pembelajaran mengharapkan seiap orang guru wajib menghadirkan media dalam proses pembelajaran, sebagaimana dikatakan Edgar Dale ada tiga hirarkis daya serap siswa. (1) Melalui praktek nyata (praktek langsung dengan cara: melihat, mengucap, mendengar, dan melakukannya). Cara ini mencapai daya serap antara 70-90 \%. (2) Mengamati (melihat) langsung gambar asli atau tiruan. Cara ini mencapai 40-60 \%. (3) Melalui bacaan dan pendengaran. Pola ini mencapai $10-30 .{ }^{26}$ Penggunaan media dinilai mampu mempertajam nalar siswa memahami, meyakini dan mengamalkan ajaran agama dengan benar dan kuat. Namun demikian, pengetahuan teoriti di

${ }^{26}$ Lihat Edgar Dale, Audiovisual Methods in Teaching (New York: Holt Rinehart and Witson, Inc, 1969), 65; Azhar Arsyad, Media pembelajaran (Jakarta: PT Raja Grafindo Persada, 1997), 10-12; Mahesh Kapadia, et al., Mendongkrak Daya Ingat bagi Orang Yang Mudah Lupa (Bandung: Jabal, 2006), edisi terjemahan, 28. 
atas mampu dilaksanakan oleh guru di Madrasah Ibtidaiyah Islahul Ummah Dasan Amman desa Peresak kecamatan Batukliang kabupaten Lombok Tengah.

Terkait dengan rendahnya kemampuan menghadirkan media pada proses pembelajaran agama, khusunya materi asmaul husna menunjukkan guru memiliki ijtihad yang sangat rendah dan tidak berani melakukan terobosan baru dalam pembelajaran. Tentu saja untuk menghadirkan media pada materi asmaul husna harus menggunakan media symbol sebagai wujud nyata pengganti materi bersifat abstrak. Sebagaimana Allah memberi contoh dengan mengambil perumpamaan pohon (media) sebagai simbol perkataan baik atau buruk untuk memperkuat pemahaman manusia dalam surat Ibarhim ayat 24 sampai 27. Secara umum, inti empat ayat ini menggambarkan bahwa Allah mengumpamakan perkataan yang baik itu ibarat pohon yang sehat dan baik serta akarnya kuat menancap dan menghujam dengan kuat dan juga memiliki cabang atau daun-daunan menjulang tinggi ke langit. Dan pohon yang sehat dan baik itu menghasilkan buah atau pahala setiap yang diberikan oleh Allah agar denga perumpamaan itu manusia selalu ingat kepadaNya. Disamping itu, Allah juga memberi perumpamaan perkataan burukdengan mengibaratkan pada sebuah pohon yang tidak sehat dan buruk keadaannya dan pohon tercabut dari akarnya dari dalam tanah dan tidak dapat tegak alias goyah atau tanpa ada sandaran sama sekali. ${ }^{27}$ Perumpamaan semacam ini menurut Manna Khalil al-Qattan disebut amtsâl musarrahaha, yaitu membandingkan dua perumpamaan antara hal yang abstrak dengan yang konkret. $^{28}$ Pola pembelajaran membuat analogi dengan bentuk konkret sesungguhnya sudah dikembangkan Umar Muhammad al-Toumy Syaibani dalam materi teologi (akidah). Ia sudah menggunakan perumpamaan dan qiyas dalam memahami materi agama bersifat abstrak. ${ }^{29}$ Karena itu, konsep pembelajaran berbasis media-simbolis sudah diterapkan dalam dunia pendidikan, akan tetapi guru agama tidak mampu mengaplikasinya dalam berbagai materi karena tidak ada keberanian berijtihad menentukan secara kreatif media-simbolis materi eskatologis dan teologis. Dan harus diakui bahwa kepercayaan dan agama

\footnotetext{
${ }^{27}$ Lihat QS Ibrahim/14: 24-27. Departemen Agama RI, al-Quran dan Terjemahnya, Surabaya; Karya Agung, edisi revisi 2006, h. 349-350.

${ }^{28}$ Lihat Heri Jauhari Muchtar, Prinsip dan Metode Pendidikan Rasulullah (Bandung: PT Remaja Rosdakarya, 2005), 217.

${ }^{29}$ Umar Muhammad al-Taomy as-Syaibani, Falsafah Pendidikan Islam (Jakarta: Bulan Bintang, 1979), edisi terjemahan, 557
} 
Transformasi, Vol. 12, No. 1, Januari 2016: 31-45

manusia klasik, bahwa pemahaman eksistensi Tuhan dalam agama bersifat simbolis. Menurut Clifford Geertz dan kawan-kawan bahwa agama dipahami sebagai seperangkat sistem simbol. ${ }^{30}$ Sama halnya dengan Islam banyak mengandung simbol, termasuk alam dan isinya adalah simbol keberadaan Tuhan. Seluruh ajaran Islam yang tertulis dalam al-Qur'an menjadi tanda (ayat) atau simbol adanya Allah. Al-Qur'an adalah firmannya sedangkan alam dan isinya adalah simbol konkret perwujudanNya.

Penggunaan media dinilai mampu mempertajam nalar siswa memahami, meyakini dan mengamalkan ajaran agama dengan benar. Karena itu, kehadiran pendekatan kontekstual untuk memadukan pendekatan teoritis dan praktis, abstrak dan konkret. Menurut Whitehead, manusia tidak sekedar diajarkan memiliki ide-ide, tetapi juga memahami penerapannya dalam situasi kehidupan nyata. ${ }^{31}$ Berpijak dari uraian di atas menunjukkan bahwa konsep pembelajaran menurut al-Quran senantiasa mengaktifkan otak manusia denagn berbagai cara, menfasilitasi alat peraga secara simbolis, dan melakukan praktek langsung sesuai konteks materi.

Dengan demikian, metode pembelajaran agama di kalangan pendidikan Islam mutlak diperbaharui (inovasi) sesuai dengan semangat zaman yang semakin rasional, pragmatis, dan konkrit. Hal ini bertentangan dengan pernyataan Ahmad Tafsir dengan argumentasi bahwa materi agama bersifat eskatalogis dan teologis, sehingga cocok dijelaskan dengan pendekatan dogmatis bukan rasional, karena agama dipahami sebagai peningkatan iman seseorang, sebab menurut Ahmad Tafsir, bahwa guru agama harus menyadari bahwa pengajaran agama pada dasarnya pengajaran doktrin bersifat normatif. Guru hanya menyampaikan ajaran Allah dan RasulNya ${ }^{32}$ Pernyataan Ahmad Tafsir tersebut dapat melemahkan sikap kritis umat Islam dan juga sikap perubahan dalam dunia pendidikan yang penuh

\footnotetext{
${ }^{30}$ Ricard C. Martin (ed.), Approaches to Islam in Religious Study, (America: The University of Arizona Press, 1985), 95; Gary E. Kessler, Philoshopy of Religion: Toward a Global Perspective (Canada: Wadsworth Publishing Company, 1999), 11; Nancy C. Ring, et.al., Introduction to the Study of Religion (New York: Orbis Books, 1998), 62-3; Ricard C. Martin (ed.), Approaches to Islam in Religious Study (Amerika: The University of Arizona Press, 1985), 95.

${ }^{31}$ Lihat Alfred N. Whitehead, "The Aims of Education" dalam The Aims of Education and Other Essays (New York: Free Press, 1967), 2.

${ }^{32}$ Lihat Ahmad Tafsir, Metodik Khusus Pengajaran Agama Islam (Bandung: Remaja Rosda Karya, 1990), 105; Ahmad Tafsir, Ilmu Pendidikan dalam Perspektif Islam (Bandung: PT Remaja Rosdakarya, 2008), 135.
} 
dinamis dan inovatif sejalan dengan perubahan dan dinamika tuntutan zaman dan perubahan akal pemikiran manusia di era teknologi dan ilmu pengetahuan yang terus berkembang dengan pesat.

Berdasarkan apa yang disampikan ahmad Tafsir di atas, dapat dipahami bahwa pernyataan Ahmad Tafsir sudah tidak sesuai semangat zaman, apalagi jika dia membaca ayat-ayat pembelajaran yang pengabdi tulis, maka akan berpikir ulang bahwa penggunaan media dalam pembelajaran dalam Islam meiliki dasar yang jelas yaitu dalam surat ar-Rahman ayat 4 yaitu allamhu al-bayan (Allah mengajarkan dengan jelas). ${ }^{33}$ Bahkan dalam buku diktat yang pengabdi tulis ada tujuh ayat yang menjelaskan di dalam al-Quran bahwa Allah membelajarkan manusia dengan dukungan media. ${ }^{34}$ Artinya, dengan adanya pelatihan berkaiatan administrasi pembelajaran berbasis media pada Madrasah Ibtidaiyah pada yayasan Islahul Ummah Nahdatul Wathan Dasan Amman desa Peresak kecamatan Batukliang kabupaten Lombok Tengah bukan sesuatu yang baru, sebab dalam empat abad yang lalu Islam sudah menjelaskan dlam kitab suci al-Quran, hanya umat Isla belum menemukan dan menetrapkan dalam proses pedidikan dan pembelajaran dalam lembaga kependidikan mulai tingkat dasar sampai perguruan tinggi.

\section{PENUTUP}

Berdasarkan uraian di atas dapat disimpulkan bahwa administrasi pembelajaran berbasis media pada guru Madrasah Ibtidaiyah pada yayasan Islahul Ummah Nahdatul Wathan Dasan Amman desa Peresak kecamatan Batukliang kabupaten Lombok Tengah dapat berjalan dengan baik. Para dewan guru sangat antusias mengikuti pelatihan dan juga aplikasi yang dilakukan para guru dalam ruangan kelas. Para guru mampu melaksnakan proses pembelajaran dengan dukungan media yang mnejelaskan materi dan siswa juga sangat terbantu dengan media yang dibawa guru ke dalam kelas sehingga memudahkan siswa dan siswi mereka dalam memahami matei mata pelajaran yang sudah disampaikan gurunya. Apalagi adanya pendampingan yang dilakukan guru bantu untuk memantau dan

\footnotetext{
${ }^{33}$ Lihat Yayasan al-Sofa (Mushaf Hilal), al-Quran dan Terjemahnya, Jakartaa, Pustaka Ifatih, 2012, h.531.

${ }^{34}$ Lhat Syukri, Ayat-Ayat Pembelajaran, Diktat. Tidak Diterbitkan, IAIN Mataram, Mataram , 2015., h. 10-17.
} 
Transformasi, Vol. 12, No. 1, Januari 2016: 31-45

memberi motivasi serta memberi solusi sementara dalam berusaha memenuhi media pendukung dalam proses pembelajaran yang dilaksanakan ibu dan guru pada madrasah ibtidaiyah Islahul Ummah Dasan Amman desa Peresak kecamatan Batukliang kabupaten Lombok Tengah. Adanya pelatihan terseut member motivasi baru bagi guru dan juga phak sekolah karena mereka mau berbenah diri lebih baik dari sebelumnya yakni memebuat rencana pelaksanaan pembelajaran (RPP) berbasis media. Pihak sekolah yayasan IslahulUmmah Nahdatul Wathan Dasan Amman desa Peresak kecamatan Batukliang kabupaten Lombok Tengah bertekad merubah diri dengan melakukan perbaikan awal di bidang administrasi pembelajaran dengan melakukan workshop ulang demi memantapkan penyusunan administrasi pembelajarn berbasis media yang sangat baik baik kemajuan siswa mereka.

Sesuai dengan hasil pembinaan kepada para guru Madrasah Ibtidaiyah pada yayasan Islahul Ummah Nahdatul Wathan Dasan Amman desa Peresak kecamatan Batukliang Lombok Tengah yang sudah berhasil mewujudkan media pembelajaran pada berbagai materi ajar yag mereka lakukan, semaoga media yang sudah disiapkan dan diadakan itu tetap dipelihara dan dirawat dengan baik sebagai bahan media pembelajaran pada materi yang akan diajarkan pada siswa yang akan datang. Mudah-mudahan dengan adanya tampilan media dapat memperkuat pemahamn siswa dan meraih kemajuan dan proses pembelajaran dan pendidikan selama mereka berada di lingkungan sekolah. Adapun kendala biaya dapat disisipkan pada dana BOS sebagai dana khusus untuk pengadaan media berupa kertas karena sangat dibutuhkan pada semua guru seiap saat dalam proses pembelajaran.

\section{DAFTAR PUSTAKA}

Arsyad, Azhar, Media Pembelajaran, Jakarta: Rajagrafindo Persada, 1997.

As-Syaibani, Umar Muhammad al-Taomy, Falsafah Pendidikan Islam, Jakarta: Bulan Bintang, 1979.

Bruner, Jerome S., Toward a Theory Instruction, Cambridge: Harvad University, 1966. 
Syukri, Administrasi Pembelajaran Guru MI...

Dale, Edgar, Audiovisual Methods in Teaching, New York: Holt Rinehart and Witson, Inc, 1969.

Departemen Agama RI, al-Quran dan Terjemahnya, Surabaya; Karya Agung, edisi revisi 2006.

Kapadia, Mahesh, et al., Mendongkrak Daya Ingat bagi Orang Yang Mudah Lupa, Bandung: Jabal, 2006.

Kessler, Gary E., Philoshopy of Religion: Toward a Global Perspective, Canada: Wadsworth Publishing Company, 1999.

Martin, Ricard C., (ed.), Approaches to Islam in Religious Study, Amerika: The University of Arizona Press, 1985.

Muchtar, Heri Jauhari, Prinsip dan Metode Pendidikan Rasulullah, Bandung: PT Remaja Rosdakarya, 2005.

Ring, Nancy C., et.al., Introduction to the Study of Religion, New York: Orbis Books, 1998.

Syukri, Ayat-Ayat Pembelajaran, Diktat. Tidak Diterbitkan, Fakultas Ilmu Tarbiyah dan Keguruan IAIN Mataram, Mataram, 2015.

--------, Metodologi Pendidikan dan Pengajaran Agama di era Global, Studi Kasus SMA Islamic Village Tangerang, Jakarta: Young Progresive Muslim, 2012.

Tafsir, Ahmad Ilmu Pendidikan dalam Perspektif Islam, Bandung: PT Remaja Rosdakarya, 2008.

--------, Metodik Khusus Pengajaran Agama Islam, Bandung: Remaja Rosda Karya, 1990.

--------, Metodologi Pengajaran Agama Islam, Bandung: PT. Remaja Rosda Karya, cetaka keenam, 2002.

Whitehead, Alfred N., "The Aims of Education" dalam The Aims of Education and Other Essays, New York: Free Press, 1967.

Yayasan al-Sofa (Mushaf Hilal), al-Quran dan Terjemahnya, Jakarta: Pustaka alFatih, 2012. 